\title{
Erratum: ABC ATPase signature helices in Rad50 link nucleotide state to Mre11 interface for DNA repair
}

Gareth J Williams, R Scott Williams, Jessica S Williams, Gabriel Moncalian, Andrew S Arvai, Oliver Limbo, Grant Guenther, Soumita SilDas, Michal Hammel, Paul Russell \& John A Tainer Nat. Struct. Mol. Biol. 18, 423-431 (2011); published online 27 March 2011; corrected after print 6 April 2011

In the version of this article initially published, the acronym ENIGMA was spelled out incorrectly in the Acknowledgments section. The error has been corrected in the HTML and PDF versions of the article.

\section{Corrigendum: Genome-wide identification of Ago2 binding sites from mouse embryonic stem cells with and without mature microRNAs}

Anthony K L Leung, Amanda G Young, Arjun Bhutkar, Grace X Zheng, Andrew D Bosson, Cydney B Nielsen \& Phillip A Sharp Nat. Struct. Mol. Biol. 18, 237-244 (2011); published online 23 January 2011; corrected after print 12 May 2011

In the version of this article initially published, the blue curve in Figure $2 \mathrm{c}$ was mistakenly replaced with a duplicate of that in Figure $2 \mathrm{a}$. The error has been corrected in the HTML and PDF versions of the article.

Erratum: Genome-wide CTCF distribution in vertebrates defines equivalent sites that aid the identification of disease-associated genes

David Martin, Cristina Pantoja, Ana Fernández Miñán, Christian Valdes-Quezada, Eduardo Moltó, Fuencisla Matesanz,

Ozren Bogdanović, Elisa de la Calle-Mustienes, Orlando Domínguez, Leila Taher, Mayra Furlan-Magaril, Antonio Alcina, Susana Cañón, María Fedetz, María A Blasco, Paulo S Pereira, Ivan Ovcharenko, Félix Recillas-Targa, Lluís Montoliu, Miguel Manzanares, Roderic Guigó, Manuel Serrano, Fernando Casares, \& José Luis Gómez-Skarmeta

Nat. Struct. Mol. Biol. 18, 708-714 (2011); published online 22 May 2011; corrected after print 3 June 2011.

In the version of this article initially published, the affiliation for authors at the Department of Molecular and Cellular Biology, Centro Nacional de Biotecnología, Madrid, Spain, was incomplete. The full affiliation is "Department of Molecular and Cellular Biology, Centro Nacional de Biotecnología, CSIC, Madrid, Spain." The error has been corrected in the HTML and PDF versions of the article.

Corrigendum: The resistance of DMC1 D-loops to dissociation may account for the DMC1 requirement in meiosis

Dmitry V Bugreev, Roberto J Pezza, Olga M Mazina, Oleg N Voloshin, R Daniel Camerini-Otero \& Alexander V Mazin Nat. Struct. Mol. Biol. 18, 56-60 (2011); published online 12 December 2010; corrected after print 9 August 2011

In the version of this article initially published, the legend for Figure $2 \mathrm{~d}$,e did not include the source of the data in those panels. These data originally appeared in ref. 20. The error has been corrected in the HTML and PDF versions of the article. 